IZA DP No. 9210

Income Inequality in Bolivia, Colombia, and Ecuador: Different Reasons

María Aristizábal-Ramírez

Gustavo Canavire-Bacarreza

Michael Jetter

July 2015 


\title{
Income Inequality in Bolivia, Colombia, and Ecuador: Different Reasons
}

\author{
María Aristizábal-Ramírez \\ Universidad EAFIT \\ Gustavo Canavire-Bacarreza \\ Universidad EAFIT and IZA \\ Michael Jetter \\ University of Western Australia and IZA
}

Discussion Paper No. 9210

July 2015

IZA

P.O. Box 7240

53072 Bonn

Germany

Phone: +49-228-3894-0

Fax: +49-228-3894-180

E-mail: iza@iza.org

\begin{abstract}
Any opinions expressed here are those of the author(s) and not those of IZA. Research published in this series may include views on policy, but the institute itself takes no institutional policy positions. The IZA research network is committed to the IZA Guiding Principles of Research Integrity.

The Institute for the Study of Labor (IZA) in Bonn is a local and virtual international research center and a place of communication between science, politics and business. IZA is an independent nonprofit organization supported by Deutsche Post Foundation. The center is associated with the University of Bonn and offers a stimulating research environment through its international network, workshops and conferences, data service, project support, research visits and doctoral program. IZA engages in (i) original and internationally competitive research in all fields of labor economics, (ii) development of policy concepts, and (iii) dissemination of research results and concepts to the interested public.
\end{abstract}

IZA Discussion Papers often represent preliminary work and are circulated to encourage discussion. Citation of such a paper should account for its provisional character. A revised version may be available directly from the author. 
IZA Discussion Paper No. 9210

July 2015

\section{ABSTRACT \\ Income Inequality in Bolivia, Colombia, and Ecuador: Different Reasons}

This paper analyzes the individual-level determinants of wage inequality for Bolivia, Colombia, and Ecuador from 2001 to 2010. Using a rich annual data set from surveys in all three countries, we analyze wages both using conventional wage regressions and decompositions of standard Gini indices. Although popular opinion and standard Gini indices suggest Colombia to exhibit the most unequal distribution of income among these countries, our results suggest otherwise. If one assumes educational attainment to form part of one's own responsibility the Colombian income distribution appears more equal than Bolivia's or Ecuador's. In 2010, educational achievement explains over 10.9 percent of the Gini score in Colombia, 6.3 percent in Ecuador, and a mere 2.4 percent in Bolivia. Our findings show that the sources of income inequality can differ substantially across countries. Respective policy prescriptions should differ accordingly.

JEL Classification: D31, D63, J31

Keywords: income inequality, Gini coefficient, unfair inequality

Corresponding author:

Michael Jetter

University of Western Australia

8716 Hackett Drive

Crawley, WA 6009

Australia

E-mail: mjetter7@gmail.com 


\section{Introduction}

Economic inequality has emerged as a primary topic in politics and economics. Especially Latin American countries continue to exhibit large degrees of income inequality: 15 of the 25 most unequal nations on earth are located in Latin America, according to the Gini index derived by the United Nations. Several historical explanations have been proposed for this development, such as the formation of extractive institutions (Acemoglu et al., 2005) or the lack of a modernization period introducing welfare states (Williamson, 2015). Although these broad explanations are helpful in understanding the origins of income inequality, they provide little practical guidance for policymakers. For example, designing potential policy solutions to inequality would differ drastically if inequality today was mostly due to, say, educational differences, as opposed to gender or racial differences.

This paper analyzes the sources of income inequality in three South American countries that have taken very different political paths to combat large inequality: Bolivia, Colombia, and Ecuador. Bolivia and Ecuador have focused on redistribution and equality, whereas Colombia has emphasized economic growth, prosperity, and especially domestic security. At first glance, Bolivia and Ecuador have substantially reduced income inequality from 2001 to 2010, whereas inequality in Colombia has changed very little in that time frame, as displayed by plotting the standard Gini index in Figure 1.

However, the standard Gini does not address the immediate sources of wage inequality. We apply a recently developed econometric technique (Almås et al., 2011; Almås et al., 2012) of analyzing individual-level data in isolating the determinants of wage inequality. This process allows us to filter out what part of the Gini index can be traced to differences in hours worked, educational attainment, and occupational choices. We derive an adjusted Gini, where income inequality resulting from so-called responsibility factors (i.e., considered as a fair source of in-

equality) is used to calculate the reference point of a fair income distribution. As a result, only inequality from non-responsibility factors (i.e., inequality from unfair determinants) remains.

Of course, everyone has different ideas of what should be considered as part of one's responsibility. For example, most people would probably agree that pure effort levels, such as hours worked, should be within the realm of one's responsibility. As a consequence, the estimation would consider all inequalities resulting from hours worked as fair and the resulting adjusted 

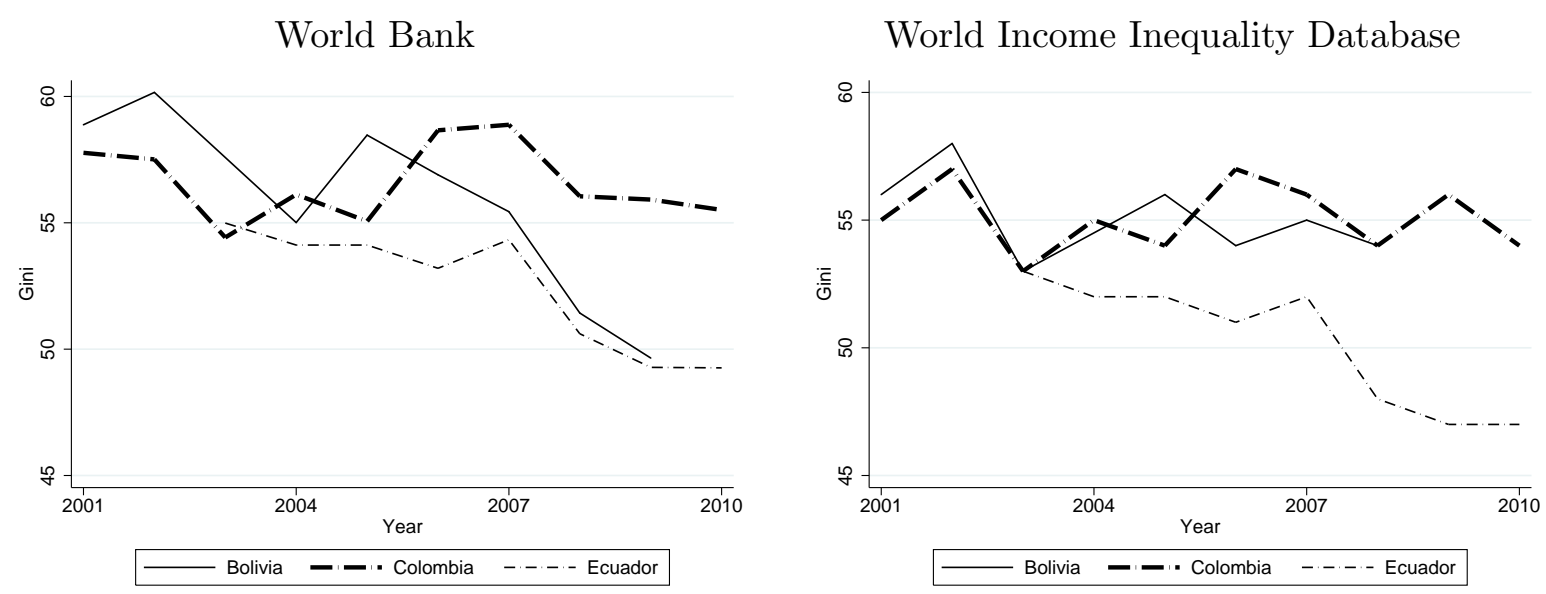

Figure 1: Notable Gini indices over time from The World Bank (2014) and UNU-WIDER World Income Inequality Database (2008).

Gini would only incorporate inequalities from other factors. Differences in gender or race, however, would probably be considered as an unfair reason for unequal payment by most people. To acknowledge different preferences in terms of what the reader may consider as fair and unfair sources of inequality, we offer several specifications, where we incorporate different sets of wage determinants into the set of responsibility factors.

Our findings are surprising and provide quite a different picture than the one displayed in Figure 1. Most notably, Colombia's wage distribution in 2010 is actually more equal than Bolivia's or Ecuador's if we consider hours worked and educational attainment as part of one's responsibility. In fact, 14 percent of the standard Gini in Colombia can be explained by hours worked and education, as opposed to two and ten percent in Bolivia and Ecuador. Over time, hours worked and education have remained stable in Colombia and Ecuador, but have dramatically decreased in Bolivia, from 13 percent in 2001 to two percent in 2010.

The paper is structured as follows. Section 2 presents a short background of our sample countries. Section 3 introduces our data and methodology. Section 4 presents our empirical findings and section 5 concludes. 


\section{Background}

The political landscape in Latin America has seen substantial changes over the past decades. In general, some countries have decidedly moved toward what is conventionally considered leftwing policies, most notably Bolivia and Ecuador. A second group of countries has moved away from democratic principles and, although disguised as leftist regimes, moved toward more authoritarian regimes, such as Venezuela or more recently Argentina. Finally, a third, smaller group of countries have implemented more free-market policies, such as Colombia or Peru.

It is well possible that one reason for a leftward move of several countries lies in the persistent inequality in many Latin American societies. For example, both the governments of Bolivia and Ecuador consider inequality as a primary problem and have developed several policies aimed at combatting inequality. Bolivia elected Evo Morales in 2005 and Rafael Correa was elected in Ecuador in 2007. Both governments have articulated a left-wing political economy, emphasizing an end of the elite's privileges and expanding welfare programs (Grugel and Riggirozzi, 2012). Both governments have started reforms to strengthen the political base. Bolivia, for example, created the Hydrocarbons Law (Ley de Hidrocarburos) in 2008, increasing the royalty tax by 18 percent, in addition to raising direct taxes by 32 percent. Evo Morales increased the government's participation in the energy sector and focused on funding social programs. Ecuador not only increased export taxes but also renegotiated contracts with oil companies (Grugel and Riggirozzi, 2012; Mosley, 2012).

Colombia, however, stands in contrast to these developments. Especially from 2002 to 2010, Álvaro Uribe has formed a government focused on free-market principles and national security, most notably a much more aggressive approach toward the Revolutionary Armed Forces of Colombia (FARC). Uribe organized his politics in terms of rebuilding the feelings of safety and around guaranteeing private investment to promote economic growth (Departamento Nacional de Planeación, 2003; Departamento Nacional de Planeación, 2007), which could be associated with the neo-liberal model implemented in Latin America over the nineties (Gwynne and Kay, 2000). For example, in 2003, Colombia conducted a major labor market reform with the goal to make the labor market more flexible and to diminish the cost of labor. One often articulated critique of the Uribe era is that the corresponding policies have not focused enough on inequality and redistributional aspects. 
The following pages are intended to evaluate the sources of inequality in Bolivia, Colombia, and Ecuador from 2001 to 2010. We build our analysis on the econometric technique introduced by Almås et al. (2011), which allows us to derive an adjusted Gini in which one can choose wage determinants that would not enter the Gini, but rather that are used to derive the benchmark of a fair distribution of income.

Essentially, the standard Gini represents a special case of this generalization where we assume that a uniform income distribution is the most equal distribution, therefore receiving a Gini score of 0. Almås et al. (2011)'s technique, however, derives a new fairness ideal in which characteristics that are deemed as responsibility factors (e.g., hours worked) are used to derive the fair distribution of income. This corresponds to a responsibility-sensitive approach of distribution (Bossert and Fleurbaey, 1996; Devooght, 2008). The adjusted Gini then produces a measure for the remaining income inequality that is not explained by responsibility factors. In the language of Almås et al. (2011), this adjusted Gini is then labeled as a measurement for "unfair" inequality, i.e., inequality owed to non-responsibility factors.

\section{$3 \quad$ Data and Methodology}

\subsection{Data}

To estimate adjusted and standard Ginis, we use annual data from national labor surveys conducted in Bolivia, Colombia, and Ecuador for the years 2001 to 2010. It is important to note that the Colombian data in the years 2006 and 2007 has been labeled as being incomparable to the remaining years. ${ }^{1}$ Nevertheless, our results are not affected by these years. Our analysis focuses on observations of employed people between 15 and 65 years old, consistent with the methodology used by Almås et al. (2011). For each country, we choose the variable corresponding to the wage income from the individual's main labor activity as the outcome variable.

Table 1 displays summary statistics for all three samples. Colombia displays the largest number of observations, as the country counts approximately five times the population of Bo-

\footnotetext{
${ }^{1}$ In 2006, Colombia's statistical institution, the Departamento Administrativo Nacional de Estadística (DANE), changed its survey methodology with the intention to obtain better and more complete data on labor markets. However, this change caused confusion as a lot of questions were not answered completely, whereas others were changed in ways that made them incomparable to previous years. For that reason, Farné (2010) suggests avoiding comparisons with these years.
} 
livia (48.3 million versus 10.6 million) and more than three times the populace of Ecuador (15.7 million). On average, reported monthly wages range from US $\$ 172$ in Bolivia to US $\$ 277$ in Ecuador. We observe substantial differences in terms of hours worked and educational attainment. Specifically, the average Colombian in our sample is working more hours and achieves a higher educational level than the average Bolivian. Note that all three countries have implemented regulations for maximum working hours. In Colombia and Bolivia, the limit is 48 hours, but 40 hours in Ecuador. It is interesting to see that average hours worked in Ecuador exceed the regulation. Informality does not appear to be the underlying reason, as only four percent of respondents in Ecuador report working informally. In Bolivia and Colombia, however, nearly 50 percent of the respondents admit to working in the informal sector - a number consistent with informality levels in the region (International Labour Organization, 2014).

In addition, we find substantial differences in educational attainment. 23 percent of the Colombian respondents states at least some university education, whereas this is true for only one out of five respondents in Bolivia and Ecuador, where 50 percent of the individuals have not studied beyond the primary education level. Note that we group educational attainment into four categories: no education, primary education, (some) secondary education, and (some) tertiary education. Although these classifications are general, this definition allows for consistency between all country samples.

With the data described above, we first estimate standard Gini coefficients, as displayed in Figure 2. Consistent with the Gini indices derived by the World Bank and the World Income Inequality Database (WIID), Bolivia's income distribution was more unequal than Colombia's or Ecuador's at the beginning of the 21st century. However, this order was reversed through the years. Ten years later, Colombia displays the most unequal society when looking at the standard Gini index. Note that Gini estimations can vary across sources. Especially in developing nations, it is difficult to derive an exact Gini measure, since many people work in the informal sector and do not access official markets. Nevertheless, our survey data seems to replicate the general trends in inequality from the World Bank and the WIID relatively well. In fact, our estimations show a greater decline in inequality in Ecuador and Bolivia than the ones presented by Lustig et al. (2013), who consider a broader definition of income. Thus, if anything, our data for Bolivia and Ecuador may overstate the reduction in inequality. 
Table 1: Summary Statistics

\begin{tabular}{|c|c|c|c|}
\hline \multirow[b]{2}{*}{ Variable } & \multicolumn{3}{|c|}{$\begin{array}{c}\text { Mean } \\
\text { (Std. Dev.) }\end{array}$} \\
\hline & Bolivia & Colombia & Ecuador \\
\hline Monthly wage in US\$ & $\begin{array}{c}171.97 \\
(254.11)\end{array}$ & $\begin{array}{c}268.50 \\
(645.40)\end{array}$ & $\begin{array}{c}276.81 \\
(458.01)\end{array}$ \\
\hline Hours worked & $\begin{array}{c}39.00 \\
(14.66)\end{array}$ & $\begin{array}{c}46.89 \\
(16.18)\end{array}$ & $\begin{array}{c}42.59 \\
(15.67)\end{array}$ \\
\hline No Education & $\begin{array}{c}0.06 \\
(0.24)\end{array}$ & $\begin{array}{c}0.03 \\
(0.17)\end{array}$ & $\begin{array}{c}0.05 \\
(0.21)\end{array}$ \\
\hline Primary education & $\begin{array}{c}0.27 \\
(0.45)\end{array}$ & $\begin{array}{c}0.25 \\
(0.44)\end{array}$ & $\begin{array}{c}0.46 \\
(0.50)\end{array}$ \\
\hline Secondary education & $\begin{array}{c}0.47 \\
(0.50)\end{array}$ & $\begin{array}{c}0.49 \\
(0.50)\end{array}$ & $\begin{array}{c}0.31 \\
(0.46)\end{array}$ \\
\hline Tertiary education & $\begin{array}{c}0.20 \\
(0.40)\end{array}$ & $\begin{array}{c}0.23 \\
(0.42)\end{array}$ & $\begin{array}{c}0.19 \\
(0.39)\end{array}$ \\
\hline Public sector & $\begin{array}{c}0.14 \\
(0.0 .35)\end{array}$ & $\begin{array}{c}0.07 \\
(0.26)\end{array}$ & $\begin{array}{c}0.11 \\
(0.31)\end{array}$ \\
\hline Informal sector & $\begin{array}{c}0.45 \\
(0.50)\end{array}$ & $\begin{array}{c}0.45 \\
(0.50)\end{array}$ & $\begin{array}{c}0.04 \\
(0.20)\end{array}$ \\
\hline Age & $\begin{array}{c}37.57 \\
(12.56)\end{array}$ & $\begin{array}{c}36.87 \\
(11.84)\end{array}$ & $\begin{array}{c}37.87 \\
(13.12)\end{array}$ \\
\hline Female & $\begin{array}{l}0.38 \\
(0.49)\end{array}$ & $\begin{array}{c}0.45 \\
(0.50)\end{array}$ & $\begin{array}{c}0.36 \\
(0.48)\end{array}$ \\
\hline$N$ & 58,000 & $2,639,428$ & 245,405 \\
\hline
\end{tabular}




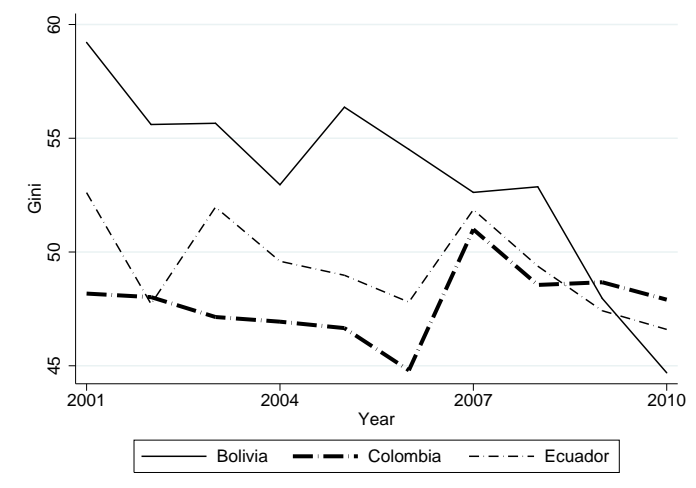

Figure 2: The conventional Gini derived from sample data.

\subsection{Methodology}

To analyze distributional aspects of wage income in all three countries, we first estimate conventional wage regressions for the first three years of the decade (2001 to 2003) and the last three years (2008 to 2010). For each country, we estimate individual $i$ 's wage $y$ in year $t$ as

$$
\ln \left(y_{i, t}\right)=\alpha_{0}+\alpha_{1} \boldsymbol{X}_{\boldsymbol{i}}+\alpha_{2} \boldsymbol{\tau}_{\boldsymbol{t}}+\alpha_{3} \boldsymbol{\lambda}_{\boldsymbol{j}}+\epsilon_{i, t}
$$

where $X_{i}$ incorporates the wage determinants described above, namely hours worked, educational attainment (secondary and tertiary education, with primary forming the reference category), occupational categories, and demographics (gender and age, linear and squared). $\tau_{t}$ represents year-fixed effects, whereas $\lambda_{j}$ stands for $j$ regional fixed affects. Finally, $\epsilon_{t}$ represents the usual error term.

Note that, although our survey data is relatively complete with respect to conventional wage regressions, some potential wage determinants recognized in the corresponding literature are absent in equation 1 because of data availability. For instance, we do not have information for individual preferences, the quality of education institutions, field of study, family characteristics, and noncognitive skills (Bowles et al., 2001; Goldin and Katz, 2008; Grove et al., 2011). To proxy for field of study we incorporate occupational fixed effects in our study.

Beyond conventional wage regressions, we estimate several adjusted Gini indices. We aim to analyze the implications of responsibility-sensitive theories of justice for the evaluation of income distribution in Bolivia, Colombia, and Ecuador during the period from 2001 to 2010. 
This theory of justice specifies that income inequalities explained by individual decisions should be accepted, in contrast to inequalities arising from non-responsibility factors (Cappelen and Tungodden, 2006; Devooght, 2008). Nevertheless, we recognize that determining which factors fall in the realm of one's responsibility remains a subjective exercise and remain agnostic along those lines. Specifically, we offer several responsibility cutoffs, allowing the reader to choose her own definition as to which wage determinants should be considered as fair sources of income.

Specifically, we closely follow the methodology applied by Almås et al. (2011), who analyze the development of the income distribution in Norway. Instead of ranking individuals based on average income (as the standard Gini does), this methodology ranks individuals according to the difference between their actual income and what would be considered their fair income, given responsibility factors. Specifically, the "fair" income is derived following the application of the generalized proportionality principle (Cappelen and Tungodden, 2006), which states that individuals who share the same characteristics in terms of responsibility factors should enjoy the same income. For example, if we were to say that hours worked are a fair source of income, then any income inequality resulting from differences in hours worked would not be considered by that adjusted Gini. Mathematically, this idea corresponds to equation (5) in Almås et al. (2011):

$$
z_{i}^{G P P}=\frac{g\left(\mathbf{x}_{i}^{R} ; \cdot\right)}{\sum_{j} g\left(\mathbf{x}_{i}^{R} ; \cdot\right)} \sum_{i} y_{i},
$$

where $z^{G P P}$ captures the individual's fair income. $g\left(\mathbf{x}_{i}^{R} ; \cdot\right)$ denotes the income function of responsibility factors, considering that all individuals are identical to all non-responsibility factors and $y_{i}$ represents the actual income. The derivation of the adjusted Gini is then based on ranking individuals by $z_{i}^{G P P}$. In our application of this methodology, we follow the sequence proposed by Almås et al. (2011), intended to capture the degree of responsibility involved. We start by selecting only the hours of work as part of the responsibility factors and then gradually add educational characteristics, job sector, and fixed effects for regions. Note that we select the same educational categories for all our three samples: (some) primary education, secondary education, and tertiary education. Overall, all variable definitions are equivalent across samples, facilitating comparability across our results.

Beyond Almås et al. (2011), this methodology has been applied to analyzing inequality 
developments in Brazil by Figueiredo and Junior (2014) from 1995 to 2009. Similarly, Carpantier and Sapata (2013) use this methodology to compare inequality of opportunity in French regions.

\section{Empirical Findings}

\subsection{Labor Earnings Equations}

We start by estimating conventional wage regressions, as outlined in equation 1. Specifically, we estimate two regressions for each of our sample countries: one including the years 2001, 2002, and 2003 and another considering the years 2008, 2009, and 2010. Although we could well choose other time frames, we wish to emphasize the labor market situation at the end of our sample compared to the beginning of the decade.

Table 2 displays the corresponding results. Not surprisingly, additional working hours are rewarded with a higher wage in all subsamples. In general, one additional hour of work translates to a $1.5-2.1$ percent increase in wage. Second, with (some) primary education forming the omitted category, substantial country differences emerge when looking at the returns to education. For both time frames, having a secondary education increases wages by over 30 percent in Colombia. In Bolivia and Ecuador, however, this semi-elasticity only reaches 23 percent (Ecuador in the more recent subsample). Somewhat surprisingly, at the end of the decade, a secondary education in Bolivia only increased one's wage by 3.6 percent.

Further, the returns to education actually decreased in Bolivia and Ecuador since 2001. This trend is then confirmed when considering tertiary schooling. Relative to primary education levels, at least some university education doubles wages in Colombia, increasing salaries by 50 percent in Ecuador, but we observe no statistically significant difference in Bolivia. This result is surprising, as we would not expect a tertiary education to yield the same salary as primary education. Previously, Canavire-Bacarreza and Rios-Avila (2015) have highlighted that Bolivia has experienced "a sharp reduction in returns on higher education."

Considering a comparison between private and public sector employment, government employees are earning a substantial premium in all three countries. For Bolivia and Ecuador, the increases in salary for public sector workers confirm the announcements of Rafael Correa and Evo Morales, who put strong emphasis on public sector participation in markets. However, 
Table 2: Labor Earnings Regressions

\begin{tabular}{|c|c|c|c|c|c|c|}
\hline \multirow[b]{2}{*}{ Years } & \multicolumn{2}{|c|}{ Bolivia } & \multicolumn{2}{|c|}{ Colombia } & \multicolumn{2}{|c|}{ Ecuador } \\
\hline & $\begin{array}{c}(1) \\
01-03\end{array}$ & $\begin{array}{c}(2) \\
08-10\end{array}$ & $\begin{array}{c}(3) \\
01-03\end{array}$ & $\begin{array}{c}(4) \\
08-10\end{array}$ & $\begin{array}{c}(5) \\
01-03\end{array}$ & $\begin{array}{c}(6) \\
08-10\end{array}$ \\
\hline \multicolumn{7}{|c|}{ Dependant variable: natural logarithm of wage in US\$ } \\
\hline Hours worked & $\begin{array}{c}0.015^{* * *} \\
(0.001)\end{array}$ & $\begin{array}{c}0.016^{* * *} \\
(0.000)\end{array}$ & $\begin{array}{c}0.021^{* * *} \\
(0.000)\end{array}$ & $\begin{array}{c}0.018^{* * *} \\
(0.000)\end{array}$ & $\begin{array}{c}0.015^{* * *} \\
(0.000)\end{array}$ & $\begin{array}{c}0.019^{* * *} \\
(0.000)\end{array}$ \\
\hline Secondary education & $\begin{array}{c}0.160^{* * *} \\
(0.020)\end{array}$ & $\begin{array}{c}0.036^{* *} \\
(0.014)\end{array}$ & $\begin{array}{c}0.363^{* * *} \\
(0.002)\end{array}$ & $\begin{array}{c}0.309^{* * *} \\
(0.002)\end{array}$ & $\begin{array}{c}0.228^{* * *} \\
(0.011)\end{array}$ & $\begin{array}{c}0.191^{* * *} \\
(0.006)\end{array}$ \\
\hline Tertiary education & $\begin{array}{c}0.488^{* * *} \\
(0.033)\end{array}$ & $\begin{array}{c}0.025 \\
(0.020)\end{array}$ & $\begin{array}{c}1.143^{* * *} \\
(0.003)\end{array}$ & $\begin{array}{c}0.999^{* * *} \\
(0.003)\end{array}$ & $\begin{array}{c}0.549^{* * *} \\
(0.017)\end{array}$ & $\begin{array}{c}0.431^{* * *} \\
(0.010)\end{array}$ \\
\hline Public sector & $\begin{array}{c}0.031 \\
(0.029)\end{array}$ & $\begin{array}{c}0.188^{* * *} \\
(0.021)\end{array}$ & $\begin{array}{c}0.455^{* * *} \\
(0.004)\end{array}$ & $\begin{array}{c}0.476^{* * *} \\
(0.004)\end{array}$ & $\begin{array}{c}0.119^{* * *} \\
(0.017)\end{array}$ & $\begin{array}{c}0.527^{* * *} \\
(0.010)\end{array}$ \\
\hline Informal sector & $\begin{array}{c}-0.278^{* * *} \\
(0.021)\end{array}$ & $\begin{array}{c}-0.323^{* * *} \\
(0.016)\end{array}$ & $\begin{array}{c}-0.354^{* * *} \\
(0.002)\end{array}$ & $\begin{array}{c}-0.252^{* * *} \\
(0.002)\end{array}$ & $\begin{array}{c}-0.357^{* * *} \\
(0.022)\end{array}$ & $\begin{array}{c}-0.304^{* * *} \\
(0.014)\end{array}$ \\
\hline Female & $\begin{array}{c}-0.382^{\text {*** }} \\
(0.019)\end{array}$ & $\begin{array}{c}-0.398^{* * *} \\
(0.014)\end{array}$ & $\begin{array}{c}-0.209^{* * *} \\
(0.002)\end{array}$ & $\begin{array}{c}-0.353^{* * *} \\
(0.002)\end{array}$ & $\begin{array}{c}-0.439^{* * *} \\
(0.010)\end{array}$ & $\begin{array}{c}-0.347^{* * *} \\
(0.006)\end{array}$ \\
\hline Age (linear and squared) & yes & yes & yes & yes & yes & yes \\
\hline Occupational FE $\mathrm{FE}^{a}$ & yes & yes & yes & yes & yes & yes \\
\hline Regional $\mathrm{FE}^{b}$ & yes & yes & yes & yes & yes & yes \\
\hline Year FE & yes & yes & yes & yes & yes & yes \\
\hline$N$ & 17,082 & 18,067 & 827,413 & 816,894 & 56,874 & 80,582 \\
\hline$R^{2}$ & 0.410 & 0.460 & 0.474 & 0.434 & 0.289 & 0.426 \\
\hline
\end{tabular}

White robust standard errors in parentheses. ${ }^{*} p<0.10,{ }^{* *} p<0.05,{ }^{* * *} p<0.01$.

${ }^{a}$ Includes fixed effects for 10 occupations.

${ }^{b}$ Includes fixed effects for regions (9 in Bolivia, 14 in Colombia, and 5 in Ecuador). 
returns for government employees are by far the largest in Colombia, where the premium over private sector jobs reaches almost 50 percent. The increase of two percentage points from the early 2000s until 2010 confirms earlier findings by Arango and Posada (2007). However, note that only 7 percent of the Colombian sample are employed by the public sector, whereas the share of government workers increases to 14 and 11 percent in Bolivia and Ecuador. Thus, Colombia's government employs less workers in relative terms, but pays them a higher salary, compared to Bolivia and Ecuador.

Finally, we find substantial gender differences in earnings. Women earn up to 44 percent less than men, even when controlling for hours worked, education, occupational choices, and age. It is discouraging that the trend of punishing women in the labor market has actually intensified in Bolivia and Colombia, when comparing the results from the earlier samples to the most recent ones. Although it has been pointed out that women on average share different preferences and ethical standards than men (Grove et al., 2011), it is difficult to imagine that unobserved preferences and noncognitive skills can explain more than one third in wage differences. Thus, it is likely that gender discrimination remains high in South American labor markets and, somewhat concerning, has actually intensified in the recent past (Angel-Urdinola and Wodon, 2006; Atal et al., 2009; Badel and Peña, 2009).

\subsection{The Sources of Inequality}

From conventional wage regressions, we now move to analyzing income inequality and specifically deriving adjusted Gini indices, taking into account the inequality resulting from several definitions of responsibility factors. Figure 3 visualizes our findings, whereas Table 3 displays the entire sets of results. For ease of exposition, we discuss the results displayed in Figure 3, but Table 3 should be consulted for further details. For each country and year, we derive an adjusted Gini, following equation 2, considering six definitions of responsibility cutoffs, in addition to the standard Gini.

The first graph in Figure 3 displays the development of income inequality over time once any income differences related to hours worked are removed. The results are similar to the standard Gini (Figure 2), as Colombia has gone from being the most equal country in the early 2000s to the most unequal country in 2010. Remember that Colombian data for the years 2006 and 
Hours

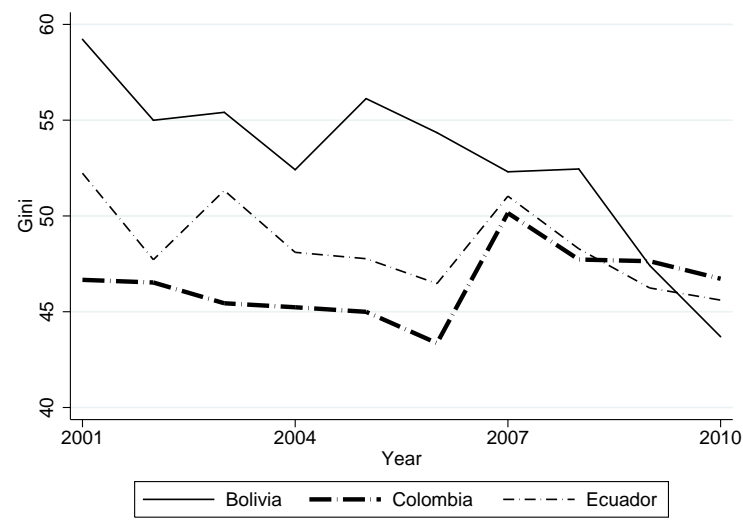

Hours, education, informal sector, occupation \& region

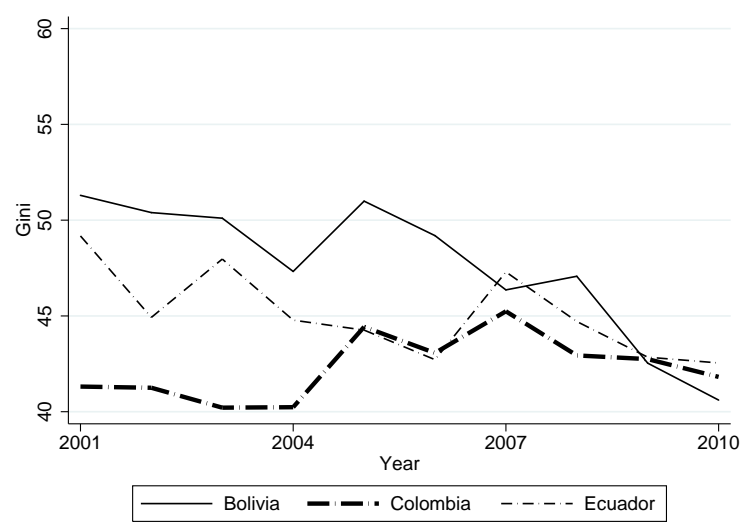

Hours \& education

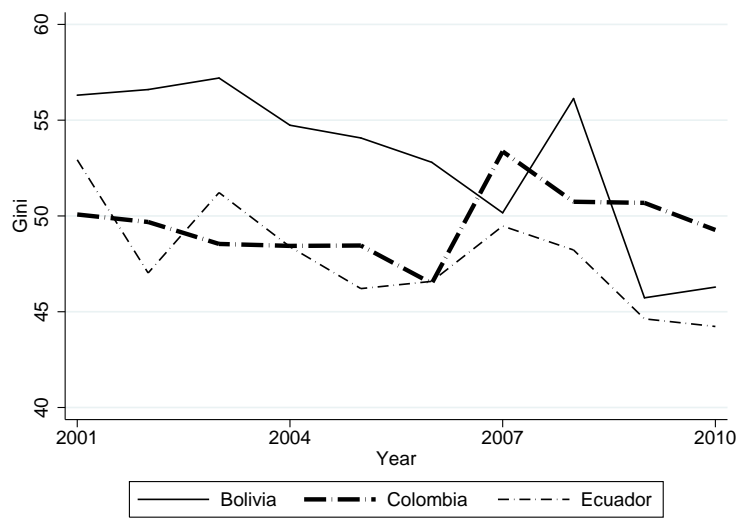

Education

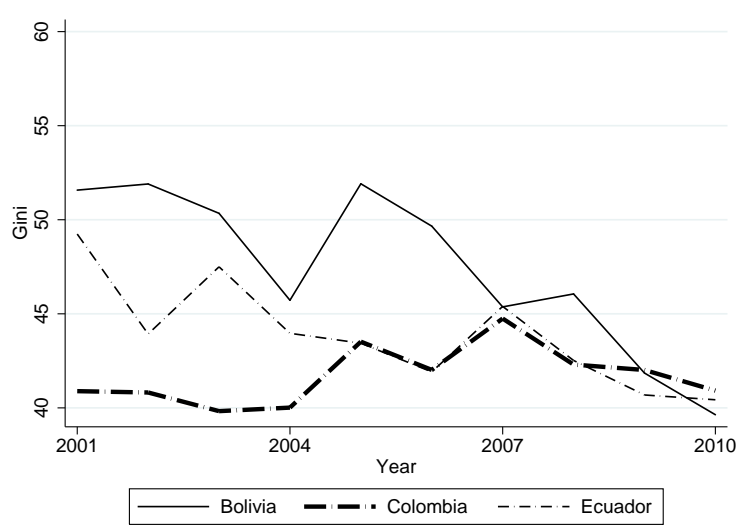

Figure 3: Adjusted Ginis over time, where headlines indicate responsibility sets. 
Table 3: Unfairness Ginis for different responsibility cuts

\begin{tabular}{|c|c|c|c|c|c|c|c|c|c|c|}
\hline \multirow[b]{2}{*}{ Responsibility Set } & \multicolumn{10}{|c|}{ Bolivia } \\
\hline & 2001 & 2002 & 2003 & 2004 & 2005 & 2006 & 2007 & 2008 & 2009 & 2010 \\
\hline Standard Gini & 9.21 & 55.60 & 55.66 & 2.96 & 56.37 & 54.51 & 52.62 & 2.87 & 1.90 & 44.69 \\
\hline$\{\mathrm{H}\}$ & 9.22 & 55.00 & 55.41 & 52.41 & 6.13 & 54.35 & 52.31 & 52.45 & 47.42 & 43.7 \\
\hline$\{\mathrm{H}, \mathrm{E}\}$ & 3.62 & 51.25 & 51.31 & 48.18 & 1.91 & 51.26 & 49.03 & 49.55 & 45.62 & 42.36 \\
\hline$\{\mathrm{H}, \mathrm{E}, \mathrm{I}\}$ & 1.53 & 50.33 & 50.02 & 47.45 & 0.86 & 49.54 & 46.64 & 46.97 & 3.10 & 10.99 \\
\hline$\{\mathrm{H}, \mathrm{E}$ & 1.81 & 1.87 & 50.40 & 45.76 & 52.04 & 49.84 & 45.52 & 45.62 & 41.70 & 39.43 \\
\hline$\{\mathrm{H}, \mathrm{E}$ & 2.19 & 2.30 & 51.17 & 45.78 & 52.4 & 49.90 & 45.73 & 46.66 & 2.33 & 39.76 \\
\hline$\{\mathrm{E}\}$ & 4.51 & 52.62 & 52.16 & 49.46 & 2.63 & 51.74 & 49.68 & 50.14 & 46.40 & 43.50 \\
\hline & \multicolumn{10}{|c|}{ Colombia } \\
\hline ibility Set & 2001 & 2002 & 2003 & 2004 & 2005 & 2006 & 2007 & 2008 & 2009 & 2010 \\
\hline Stanc & 48.17 & 48.02 & 47.14 & 46 & 6.66 & 44.80 & 51 & 5 & 48.67 & 47.91 \\
\hline$\{\mathrm{H}\}$ & 46.61 & 46.49 & 45.40 & 45.19 & 45.10 & 43 & 50 & 47 & 6 & 46.65 \\
\hline$\{\mathrm{H}, \mathrm{H}$ & 4 & 40.18 & 39 & 2 & 39.54 & 42 & 4 & 42 & 7 & 41.29 \\
\hline$\{\mathrm{H}$, & 9 & 40.77 & 39.94 & 40 & 40.17 & 43.07 & 45 & 42.91 & 4 & 41.81 \\
\hline$\{\mathrm{H}$, & 9 & 10.52 & 39 & . & 13 & 42 & 4 & 42 & 9 & 40.93 \\
\hline$\{\mathrm{H}, \mathrm{E}$, & 2 & 0.51 & 39. & . & 0.14 & 42 & 4 & 42.39 & 2 & 40.89 \\
\hline$\{\mathrm{E}\}$ & 42.19 & 42.29 & 41.48 & 41.42 & 1.28 & 43.35 & 45.81 & 43.40 & 43.39 & 42.63 \\
\hline & \multicolumn{10}{|c|}{ Ecuador } \\
\hline Res & 2 & 2 & 200 & 200 & 2005 & 20 & & 20 & 9 & 2010 \\
\hline Stand & 52.61 & 47.72 & 1. & 4 & 48.98 & 47 & 5 & 49.38 & 47 & 6.60 \\
\hline$\{\mathrm{H}\}$ & 52.23 & 47.72 & 51. & 48.10 & 47.77 & 46.47 & 5 & 48.29 & 24 & 45.61 \\
\hline$\{\mathrm{H}$, & 4 & 44.91 & 48 & 44.85 & 44.34 & 42.78 & 47 & 44.78 & 42.93 & 42.61 \\
\hline$\{\mathrm{H}$, & 4 & 44.93 & 47. & 44.78 & 44.26 & 42.72 & 4 & 44.71 & 85 & 42.55 \\
\hline$\{\mathrm{H}$, & 49.24 & 43.93 & 47.50 & 43.96 & 43.44 & 41.91 & 45.39 & 42.52 & 40.69 & 40.43 \\
\hline$\{\mathrm{H}, \mathrm{E}, \mathrm{I}, \mathrm{O}$ & 4 & 43.95 & 47. & 43. & 43.44 & 41 & 45 & 42.48 & 40.70 & 40.46 \\
\hline & 13 & 45.52 & 49.07 & 46.49 & 45.62 & 44.38 & 48.32 & 45.96 & 44.26 & 43.68 \\
\hline
\end{tabular}

Notes: We consider hours worked (H), level of education (E), working in the informal sector (I), occupation $(\mathrm{O})$, and region of residence $(\mathrm{R})$. The final Gini (right bottom) displays an alternative where only educational attainment is included as a responsibility factor. 
2007 should be considered with caution, so it appears as if at least since 2008 Colombia exhibits larger inequality than Bolivia and Ecuador.

As a next step, the top right graph incorporates educational attainment into the set of responsibility factors. The result is now reversed: Colombia remains the most equal country among our three sample economies. This means that schooling explains a much larger share of income inequality in Colombia than in Bolivia and Ecuador. Remember that our wage regressions, displayed in Table 2, have already indicated that educational aspects are rewarded much stronger in the Colombian labor market.

Notice also that Bolivia has experienced a spike in this adjusted Gini from 2009 and 2010. Although the magnitude seems small, this indicates that educational aspects are less able to explain inequality developments. Nevertheless, it is important to highlight that the adjusted Gini for hours and education in Colombia in 2010 still remains higher than that same adjusted Gini in 2001. Thus, income inequality in Colombia based on non-responsibility factors has increased also, not just the standard Gini.

The bottom left graph of Figure 3 then displays the results from deriving an adjusted Gini that incorporates hours worked, educational level, occupational choice, and regions into the set of responsibility variables. This adjusted Gini attributes virtually all aspects that can in any way be influenced by an individual toward one's own responsibility. Note that now Colombia appears as the most unequal country again, as roles are reversed. In fact, especially the variable describing public sector employment explains relatively more of income inequality in Bolivia and Ecuador than in Colombia.

Finally, the bottom right graph of Figure 3 displays results from an exercise where we only incorporate educational attainment into the set of responsibility factors. But, as before, Colombia emerges as the most equal society in 2010 once we attribute educational standards toward one's own responsibility.

\subsection{Relative Contribution of Hours Worked and Education}

The results displayed in Figure 3 indicate that once educational aspects are acknowledged as part of one's responsibility Colombia displays less income inequality than Bolivia and Ecuador. But how strong is the influence of educational parameters really? Figure 4 shows the contribution 
of hours worked and education in the standard Gini. These graphs visualize the strong role of education in Colombia and Ecuador. For Colombia, education explains 5.2 index points of the standard Gini or approximately 10.8 percent. For Ecuador, education can explain 6.2 percent of the standard Gini. These contributions are far above the role of pure hours worked with 2.2 to 3.1 percent.

Contribution of hours in absolute terms

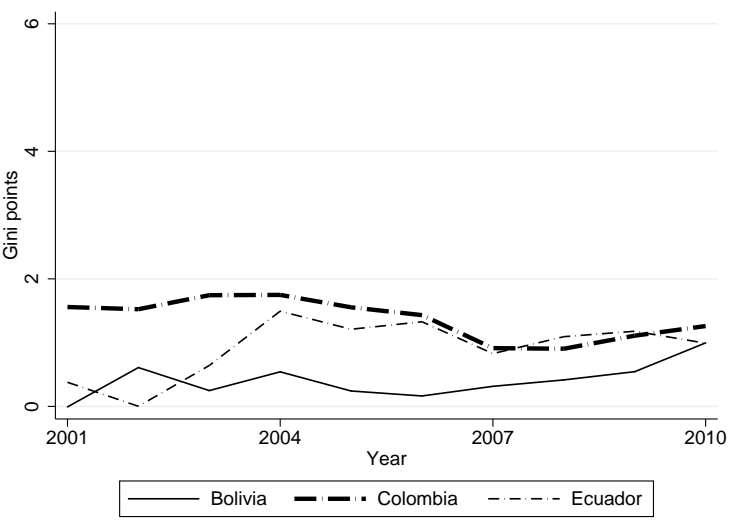

Contribution of education in absolute terms

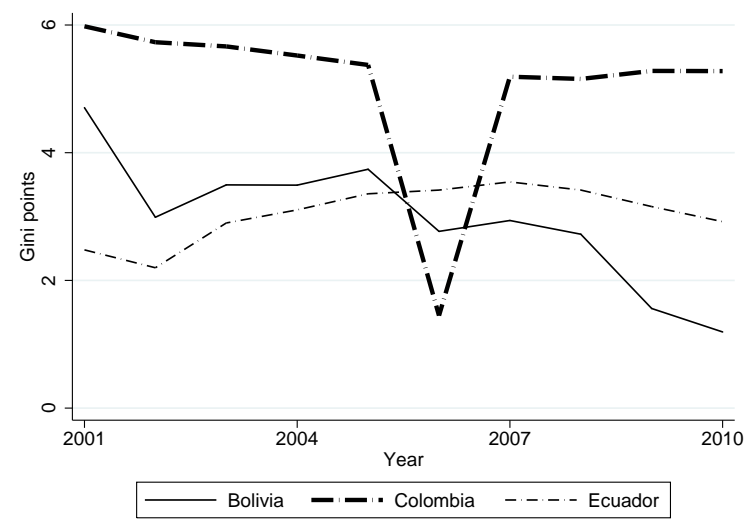

Contribution of hours in relative terms

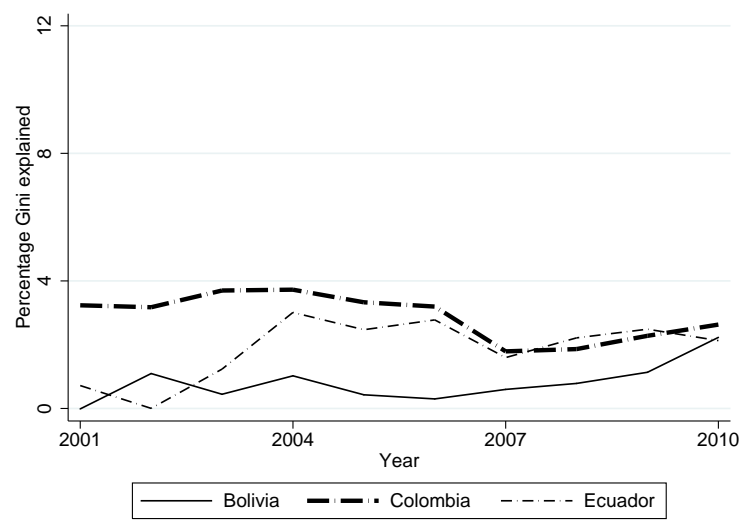

Contribution of education in relative terms

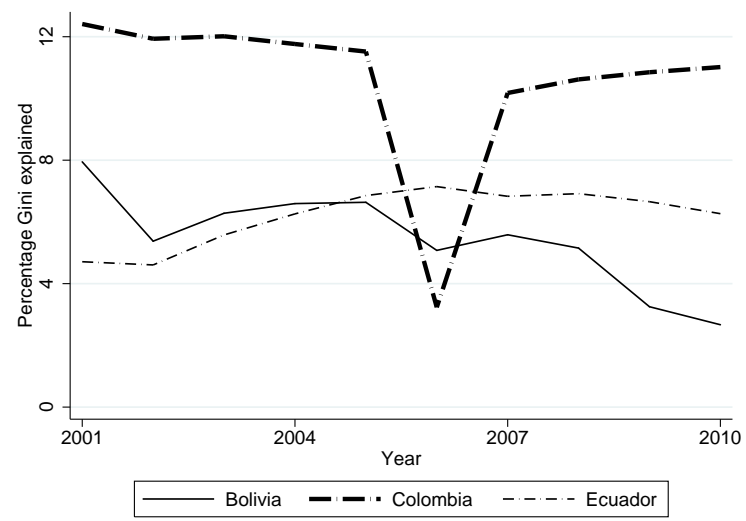

Figure 4: Portion of standard Gini explained by hours and education in absolute terms (left) and relative terms (right).

In contrast, wages in Bolivia behave differently. In 2010, hours worked there explain as much of income inequality than educational achievement. In the context of the conventional labor literature, this result comes as a surprise and appears disappointing, considering the spillover effects education can produce (Barro, 2001; Eicher and Garcia-Penalosa, 2001; Moretti, 
2004; Tamura, 2006; Iranzo and Peri, 2009; Caselli and Ciccone, 2013). Finally, considering further responsibility cuts, including aspects as informality, occupation, and region of residency produces similar distributions in our three sample countries.

\section{Conclusions}

This paper decomposes the standard Gini index for three Latin American countries (Bolivia, Colombia, and Ecuador) for annual data from 2001 to 2010. At first glance, Colombia appears to be the most unequal country in terms of income in 2010. However, if people are held accountable for their educational attainment Colombia exhibits less inequality than both Bolivia and Ecuador. These results are surprising as both the Bolivian and the Ecuadorian government have strongly focused on redistribution and income inequality.

There are several conclusions we can draw from these findings. First, education is highly valued on the Colombian labor market, less so in Ecuador, and virtually not at all in Bolivia today. This notion is confirmed by basic wage regressions and our results indicate that there exists no wage premium for a Bolivian with tertiary education compared to somebody with (some) primary schooling. This result is disappointing, given that strong positive externalities from education have been found (Barro, 2001; Eicher and Garcıa-Penalosa, 2001; Moretti, 2004; Tamura, 2006; Iranzo and Peri, 2009; Caselli and Ciccone, 2013). Another way of highlighting the importance of education for a country's development is to consider the standard growth model introduced by Mankiw et al. (1992). Thus, although Bolivia and Ecuador show remarkable progress in fighting general income inequality, the country may have paid the price with a distorted incentive structure as neither effort levels (captured in hours worked) nor education seems to be rewarded.

Second, contrary to popular opinion, inequality in Colombia in 2010 has been lower than in Ecuador and Bolivia if educational attainment is considered as part of one's responsibility. This notion can of course be challenged as education is not as easily accessible in Colombia as, say, the European Union, where school systems are largely free. Thus, one can certainly argue whether educational attainment should be considered as entirely part of one's own responsibility in Colombia and we do not wish to enter such a discussion. 
Third, and more generally, analyzing the immediate sources of income inequality is a task that should receive more attention from researchers and policymakers interested in combatting inequality. For example, policy recommendations would differ dramatically if income inequality stems mostly from education, rather than other characteristics, such as occupational regional differences. 


\section{References}

Acemoglu, D., Johnson, S., and Robinson, J. A. (2005). Institutions as a fundamental cause of long-run growth. Handbook of Economic Growth, 1:385-472.

Almås, I., Cappelen, A. W., Lind, J. T., Sørensen, E. Ø., and Tungodden, B. (2011). Measuring unfair (in) equality. Journal of Public Economics, 95(7):488-499.

Almås, I., Havnes, T., and Mogstad, M. (2012). Adjusting for age effects in cross-sectional distributions. STATA JOURNAL, 12(3):393-405.

Angel-Urdinola, D. F. and Wodon, Q. (2006). The gender wage gap and poverty in Colombia. Labour, 20(4):721-739.

Arango, L. E. and Posada, C. E. (2007). Los salarios de los funcionarios públicos en Colombia (1978-2005). Ensayos sobre Política económica, 25(55):110-147.

Atal, J., Ñopo, H., and Winder, N. (2009). New century, old disparities: gender and ethnic wage gaps in Latin America. IDB Working Paper No. 25.

Badel, A. and Peña, X. (2009). Decomposing the gender wage gap with sample selection adjustment: Evidence from Colombia. Mimeo, Universidad de las Andes.

Barro, R. J. (2001). Human capital and growth. American Economic Review, 91(2):12.

Bossert, W. and Fleurbaey, M. (1996). Redistribution and compensation. Social Choice and Welfare, 13(3):343-355.

Bowles, S., Gintis, H., and Osborne, M. (2001). The determinants of earnings: A behavioral approach. Journal of Economic Literature, 39(4):1137-1176.

Canavire-Bacarreza, G. and Rios-Avila, F. (2015). On the determinants of changes in wage inequality in Bolivia. Levy Economics Institute of Bard College Working Paper, (835).

Cappelen, A. W. and Tungodden, B. (2006). Relocating the responsibility cut: Should more responsibility imply less redistribution? Politics, Philosophy \& Economics, 5(3):353-362. 
Carpantier, J.-F. and Sapata, C. (2013). An ex-post view of inequality of opportunity in France and its regions. Journal of Labor Research, 34(3):281-311.

Caselli, F. and Ciccone, A. (2013). The contribution of schooling in development accounting: Results from a nonparametric upper bound. Journal of Development Economics, 104:199-211.

Departamento Nacional de Planeación (2003). Plan nacional de desarrollo 2002-2006. Hacia un Estado Comunitario, Departamento Nacional de Planeación, Bogotá.

Departamento Nacional de Planeación (2007). Plan nacional de desarrollo 2006-2010. Estado comunitario desarrollo para todos, Departamento Nacional de Planeación, Bogotá.

Devooght, K. (2008). To each the same and to each his own: A proposal to measure responsibility-sensitive income inequality. Economica, 75(298):280-295.

Eicher, T. S. and Garcia-Penalosa, C. (2001). Inequality and growth: the dual role of human capital in development. Journal of Development Economics, 66(1):173-197.

Farné, S. (2010). Encuestas de hogares para dummies: Cómo interpretar la transición de las encuestas continuas a la gran encuesta integrada. Technical report, Universidad Externado de Colombia.

Figueiredo, E. and Junior, J. L. d. S. N. (2014). More equal but not so fair: An analysis of Brazilian income distribution from 1995 to 2009. Empirical Economics, 46(4):1325-1337.

Goldin, C. and Katz, L. F. (2008). Transitions: Career and family life cycles of the educational elite. American Economic Review, 98(2):363-69.

Grove, W. A., Hussey, A., and Jetter, M. (2011). The gender pay gap beyond human capital: Heterogeneity in noncognitive skills and in labor market tastes. Journal of Human Resources, $46(4): 827-874$.

Grugel, J. and Riggirozzi, P. (2012). Post-neoliberalism in Latin America: Rebuilding and reclaiming the state after crisis. Development and Change, 43(1):1-21.

Gwynne, R. N. and Kay, C. (2000). Views from the periphery: Futures of neoliberalism in Latin America. Third World Quarterly, 21(1):141-156. 
International Labour Organization (2014). Global employment trends 2014: The risk of a jobless recovery. Technical report, International Labour Office.

Iranzo, S. and Peri, G. (2009). Schooling externalities, technology, and productivity: Theory and evidence from US states. Review of Economics and Statistics, 91(2):420-431.

Lustig, N., Lopez-Calva, L. F., and Ortiz-Juarez, E. (2013). Declining inequality in Latin America in the 2000s: The cases of Argentina, Brazil, and Mexico. World Development, 44:129-141.

Mankiw, N. G., Romer, D., and Weil, D. N. (1992). A contribution to the empirics of economic growth. Quarterly Journal of Economics, 107(2):407-437.

Moretti, E. (2004). Workers' education, spillovers, and productivity: Evidence from plant-level production functions. American Economic Review, 94(3):656-690.

Mosley, P. (2012). The politics of poverty reduction. Oxford University Press.

Tamura, R. (2006). Human capital and economic development. Journal of Development Economics, 79(1):26-72.

The World Bank (2014). World development indicators. GINI index (World Bank estimate): http: //data.worldbank.org/indicator/SI.POV.GINI, March.

UNU-WIDER World Income Inequality Database (2008). World income inequality database. GINI index (World Bank estimate): http: / / www . wider . unu .edu/research/Database/, Version 2.0c, May.

Williamson, J. G. (2015). Latin American inequality: Colonial origins, commodity booms, or a missed 20th century leveling? Technical report, NBER Working Paper \# 20915. 